Journal of Applied Pharmaceutical Science Vol. 5 (12), pp. 122-124, December, 2015

Available online at http://www.japsonline.com

DOI: $10.7324 / J A P S .2015 .501221$

ISSN 2231-3354 (cc) BY-NC-SA

\title{
Study of Drug-Drug Interactions in General Medicine Department of a Tertiary Care Hospital
}

\author{
Kousalya Kaliamurthy*, Anil Kumar, Saranya Punniyakotti, Praveen Devanandan \\ Department of Pharmacy Practice, School of Pharmaceutical Sciences, Vels University, Chennai, Tamil Nadu, India.
}

\section{ARTICLE INFO}

Article history:

Received on: 08/09/2015

Revised on: 21/09/2015

Accepted on: 18/10/2015

Available online: 27/12/2015

\section{Key words:}

Drug-Drug Interactions,

Drug Related Problems,

Adverse Events

\begin{abstract}
Objectives Drug therapy (DT) is growing more complex, thus appropriate drug prescription becomes increasingly challenging. Drug interactions (DI) are one of the important factors that modify the response to a drug. The main objective of this study was to monitor the potentially serious and significant Drug-Drug Interactions (DDIs).

Material and methods The number of drugs prescribed for each patient, drugs taken by the patient and the drug interactions were recorded. The interactions between the drugs were assessed using Micromedex software and Stockley's Drug Interaction. The type and severity of prescription with DDIs was also assessed.

Results The number of potential DDIs for the study population was 390 and each prescription had at least one interaction. Of the total potential DDIs $(n=390)$ identified, majority were of moderate severity $(n=257,65.90 \%)$. Most frequent DDI was seen between Metformin + Ranitidine (moderate interaction) in 70 prescriptions $(50 \%)$ and between Ranitidine + Acetaminophen (minor interaction) in 48 prescriptions (34.29\%). The common major interactions were seen between Rabeprazole + Clopidogrel in 4 prescriptions (2.86\%), Enalapril + Spironolactone and Ciprofloxacin + Tramadol in 3 prescriptions $(2.14 \%)$.

Conclusion The drug related problems, primarily the drug interactions is a permanent patient related risk in hospitals and the utilization of computer software has become the best way to identify and prevent them.
\end{abstract}

\section{INTRODUCTION}

Drug therapy (DT) is growing more complex, thus appropriate drug prescription becomes increasingly challenging. Drug interactions (DI) are one of the important factors that modify the response to a drug. Drug-Drug Interactions (DDI) can result in anything from minor morbidities up to fatal consequences. The main causes of hospital admission and mortalities are related to DI and their corresponding adverse effects (AE). It has been estimated that $10-20 \%$ of hospital admissions are caused by drug related events, and about $1 \%$ are caused by Drug Interactions (Jankel and Fitterman, 1993). Drug Interactions may produce beneficial or desirable, or undesirable or harmful effects (Doubova et al., 2007). The beneficial effects are those whose purpose is to treat concomitant disease, enhancing the effectiveness, reducing $\mathrm{AE}$ and allowing to reduce the dose, while the undesirable effects may reduce the drug

\footnotetext{
* Corresponding Author

Email: happykousi@gmail.com
}

effectiveness and may produce unwanted, noxious and even life threatening effects in the body, along with the increased treatment cost. The undesirable interactions may result in impact on the patient. DDIs can lead to alteration of therapeutic response or increase untoward effects of many drugs (Baxter and Stockley, 2010). Adding each drug combination increases chances of further DDI. Special attention and thorough monitoring is definitely required for the patients who are at the most risk of developing pDDIs (Rana et al., 2014). Now-a-days, many patients are on polypharmacy for treating their disease conditions and there are many interactions between the drugs prescribed in each prescription.

There are very less number of Drug-Drug Interaction studies that focus on type, severity of potential for adverse drugdrug interactions. The main aim and objective of this study was to monitor the potentially serious and significant Drug-Drug Interactions (DDIs), to evaluate the nature and mechanism of these interactions and to identify the common and causal drug groups for these DDIs. Hence this study was carried out to evaluate the types and severity of possible DDIs in General Medicine department. 


\section{MATERIALS AND METHODS}

This cross-sectional study was carried out in the department of General Medicine after getting approval from the Institutional Ethics Committee, School of Pharmaceutical Sciences, Vels University. All the patients coming to the inpatient general medicine department, who were greater than 18 years and who were prescribed with 4 or more drugs were included in the study.

Pregnant ladies and psychiatric patients were excluded from the study. Prior approval from all the patients was obtained in the patient consent form. The patients were followed from the time of admission till discharge. The patient demographics, details of prescribed medication and discharge medications were all recorded in a specially designed proforma. The interactions between the drugs were assessed using Micromedex software and Stockley's Drug Interaction (Baxter and Stockley, 2010). The type and severity of prescription with DDIs was also assessed.

\section{RESULTS}

In this study, 140 patients were on polypharmacy. The most common medications include anti-hypertensives and oral hypoglycaemic drugs. Majority of patients were in the age group of 51-60 years $(n=34,24.28 \%)$, followed by $41-50$ years $(n=33$, 23.57\%). Among 140 patients, majority were male. Majority of the patients do not have any social habits of smoking or drinking.

The diagnosis and co-morbidities in General Medicine department were given in table 1 .

Table 1: Diagnosis and co-morbidities in general medicine department.

\begin{tabular}{lc}
\multicolumn{1}{c}{ Co-morbidities } & No. of patients $(\mathbf{n = 1 4 0})$ \\
\hline Ischemic Heart Disease (IHD) & 10 \\
Diabetes Mellitus (DM) & 42 \\
Hypertension (HTN) & 34 \\
Gastrointestinal (GI) Problems & 32 \\
Pyrexia & 22 \\
Renal Disorders & 15 \\
Blood Disorders & 5 \\
Poisoning & 2 \\
Respiratory Problems & 27 \\
Headache/Cerebrovascular Accident (CVA) & 12 \\
Thyroid Disorders & 8 \\
Ortho Problems & 7 \\
Dermatological Problems & 3 \\
Neurological Problems & 5 \\
\hline
\end{tabular}

Among 140 prescriptions, 390 interactions were found. Among them, $51.8 \%$ were of pharmacodynamic interactions and $48.2 \%$ were of pharmacokinetic interactions.

Majority of the interactions were of moderate severity $(n=257,65.9 \%)$, followed by minor interactions $(n=120,30.77 \%)$.

The commonly found potential drug drug interactions along with the severity and number of patients were shown in table 2.

Among 390 interactions, 13 were of major interactions. The major interactions were listed in table 3 . The frequency of drug-drug interactions among 140 interactions was depicted in table 4.
Table 2: Commonly found potential Drug-Drug Interactions.

\begin{tabular}{ccc}
\hline Severity level & Interacting drugs & No. of patients \\
\hline \multirow{4}{*}{ Major } & Ciprofloxcin / Prednisolone & 2 \\
& Enalapril / Spironolactone & 3 \\
& Ciprofloxacin / Tramadol & 3 \\
& Rabeprazole / Clopidogrel & 4 \\
& Ciprofloxacin / Theophylline & 1 \\
\hline \multirow{5}{*}{ Moderate } & Metformin / Ranitidine & 70 \\
& Enalpril / Asprin & 35 \\
& Aspirin / Insulin & 51 \\
& Enalapril / Metformin & 64 \\
& Enalapril / Insulin & 37 \\
\hline \multirow{5}{*}{ Minor } & Ranitidine / Acetaminophen & 48 \\
& Enalapril / Amlodipine & 30 \\
& Aspirin / Rabeprazole & 16 \\
& Ranitidine / Diclofenac & 26 \\
\hline
\end{tabular}

Table 3: List of Major Drug-Drug Interactions.

\begin{tabular}{|c|c|c|}
\hline Drugs & $\begin{array}{c}\text { No. of patients } \\
(\%)\end{array}$ & Potential effect \\
\hline $\begin{array}{l}\text { Ciprofloxcin / } \\
\text { Prednisolone }\end{array}$ & $2(15.38 \%)$ & $\begin{array}{l}\text { Ciprofloxacin given together } \\
\text { with prednisolone can increase } \\
\text { the risk of tendinitis and tendon } \\
\text { rupture. }\end{array}$ \\
\hline $\begin{array}{l}\text { Enalapril / } \\
\text { Spironolactone }\end{array}$ & $3(23.08 \%)$ & $\begin{array}{l}\text { Concomitant use of angiotensin } \\
\text { converting enzyme (ACE) } \\
\text { inhibitors and potassium-sparing } \\
\text { diuretics may increase the risk of } \\
\text { hyperkalemia. }\end{array}$ \\
\hline $\begin{array}{l}\text { Ciprofloxacin / } \\
\text { Tramadol }\end{array}$ & $3(23.08 \%)$ & $\begin{array}{l}\text { The risk of seizures may be } \\
\text { increased during co } \\
\text { administration of tramadol with } \\
\text { any substance that can reduce the } \\
\text { seizure threshold, such as } \\
\text { selective serotonin reuptake } \\
\text { inhibitors. }\end{array}$ \\
\hline $\begin{array}{l}\text { Rabeprazole / } \\
\text { Clopidogrel }\end{array}$ & $4(30.76 \%)$ & $\begin{array}{l}\text { Co administration with proton } \\
\text { pump inhibitors (PPIs) may } \\
\text { reduce the cardio protective } \\
\text { effects of clopidogrel. }\end{array}$ \\
\hline $\begin{array}{l}\text { Ciprofloxacin / } \\
\text { Theophylline }\end{array}$ & $1(7.7 \%)$ & $\begin{array}{l}\text { Co administration with } \\
\text { ciprofloxacin may increase the } \\
\text { serum concentration of } \\
\text { theophylline and the associated } \\
\text { risk of toxicity. }\end{array}$ \\
\hline
\end{tabular}

Table 4: Frequency of drug-drug interactions.

\begin{tabular}{ccc}
\hline Frequency of DDIs & Number of patients $(\mathbf{n = 1 4 0})$ & Percentage \\
\hline 1 & 64 & $45.72 \%$ \\
2 & 14 & $10 \%$ \\
3 & 8 & $5.71 \%$ \\
4 & 14 & $10 \%$ \\
5 & 28 & $20 \%$ \\
$>5$ & 12 & $8.57 \%$ \\
\hline
\end{tabular}

\section{DISCUSSION}

Drug-drug interactions (DDIs) are a concern for all stake holders, especially patients and this risk increases as greater number of medications was commonly used to manage complex conditions. The study utilized a computer system to verify the possibilities of drug interactions in medical prescriptions.

During 6 months of study, 140 prescriptions were analysed out of which $76(54.2 \%)$ were male and 64 (45.8\%) were female. Among them, 13 prescriptions were with major interactions, 257 prescriptions with moderate and 120 prescriptions with minor interactions. Major DDIs were identified 
in about $3.33 \%$ of the study subjects and majority of the patients do not have any social habits.

Majority of the patients were in the age group of $51-60$ years $(n=34,24.28 \%)$, which was similar to the study conducted by Doubova et al., 2007.

The number of pDDIs for the study population was 390 and each prescription had at least one interaction. Of the total pDDIs $(n=390)$ identified, majority were of moderate severity $(n=$ $257,65.90 \%$ ). It was similar to the study conducted by Patel et al., 2011, Riechelmann et al., 2007, Riechelmann et al., 2008, Dinesh et al., 2007.

Of the pDDIs $(n=390)$ observed, majority were of pharmacodynamic $(n=202,51.80 \%)$ in nature followed by pharmacokinetic $(n=188,48.20 \%)$. These findings were contrast to the study reported by Vonbach et al., 2008 and Aparasu et al., 2007.

Most frequent DDI was seen between Metformin + Ranitidine (moderate interaction) in 70 prescriptions (50\%) and between Ranitidine + Acetaminophen (minor interaction) in 48 prescriptions $(34.29 \%)$. The common major interactions were seen between Rabeprazole + Clopidogrel in 4 prescriptions $(2.86 \%)$, Enalapril + Spironolactone and Ciprofloxacin + Tramadol in 3 prescriptions $(2.14 \%)$. The major interaction seen between Rabeprazole + Clopidogrel was similar to the study conducted by Juurlink et al., 2001 in which the major interaction was found between Clopidogrel and Proton Pump Inhibitors other than Pantoprazole.

\section{CONCLUSION}

The drug related problems primarily the drug interactions is a permanent patient related risk in hospitals and the utilization of computer software has become the best way to identify and prevent them. Pharmacist involvement may not only highly increase the reporting rate but also the quality of reporting. Hence the pharmacist participation in the multidisciplinary healthcare team can improve the treatment to hospitalized patients and promote drug safety.

\section{REFERENCES}

Aparasu R, Baer R, Aparasu A. Clinically important potential drug-drug interactions in outpatient settings. Res Soc Adm Pharm, 2007; 3(4):426-37.

Baxter K, Stockley I. 2010. Stockley's drug interactions. London: Pharmaceutical Press.

Dinesh KU, Subish P, Pranaya M, Shankar PR, Anil SK, Durga B. Pattern of potential drug-drug interactions in diabetic out-patients in a tertiary care teaching hospital in Nepal. Med J Malaysia, 2007; 62(4):2948 .

Doubova (Dubova) SV, Reyes-Morales H, Torres-Arreola LP, Suárez-Ortega M. Potential drug-drug and drug-disease interactions in prescriptions for ambulatory patients over 50 years of age in family medicine clinics in Mexico City. BMC Health Serv Res, 2007; 7(1):147.

Jankel C, Fitterman L. Epidemiology of drug-drug interactions as a cause of hospital admissions. Drug Saf, 1993; 9(1):51-9.

Juurlink DN, Gomes T, Ko DT, Szmitko PE, Austin PC, Tu JV, et al. A population-based study of the drug interaction between proton pump inhibitors and clopidogrel. CMAJ, 2009; 180(7):713-8.

Patel V, Acharya LD, Rajakannan T, Surulivelrajan M, Guddattu V, Padmakumar R. Potential drug interactions in patients admitted to cardiology wards of a south Indian teaching hospital. Australas Med J, 2011; 4(1):9-14.

Rana D, Suthar J, Malhotra S, Patel V, Patel P. A study of potential adverse drug-drug interactions among prescribed drugs in medicine outpatient department of a tertiary care teaching hospital. J Basic Clin Pharma, 2014; 5(2):44.

Riechelmann RP, Tannock IF, Wang L, Saad ED, Taback NA, Krzyzanowska MK. Potential drug interactions and duplicate prescriptions among cancer patients. J Natl Cancer Inst, 2007; 99(8):592-600.

Riechelmann RP, Zimmermann C, Chin SN, Wang L, O'Carroll A, Zarinehbaf $\mathrm{S}$, et al. Potential drug interactions in cancer patients receiving supportive care exclusively. J Pain Symptom Manage, 2008; 35(5):535-43.

Vonbach P, Dubied A, Krähenbühl S, Beer JH. Prevalence of drug-drug interactions at hospital entry and during hospital stay of patients in internal medicine. Eur J Intern Med, 2008; 19(6):413-20.

\section{How to cite this article:}

Kaliamurthy K, Kumar A, Punniyakotti S, Devanandan P. Study of Drug-Drug Interactions in General Medicine Department of a Tertiary Care Hospital. J App Pharm Sci, 2015; 5 (12): 122-124. 